the Moorlands of England and Wales and Its Relevance for Conservation'; b) Dr Olaf Peterson, for his paper entitled 'The History of Lake Hornborga: A Lesson in Wetland Function and Management from Sweden'; c) Dr Robert J.A. Goodland, Dr Emmanuel O.A. Asibey, Jan C. Post \& Mary B. Dyson, for their paper entitled 'Tropical Moist Forest Management: The Urgency of Transition to Sustainability'; and d) Karen Holl, Gretchen Daily \& Professor Paul R. Ehrlich, for their paper entitled 'Integrated Pest Management in Latin America'. Choice of the winners of these yearly awards is purely by the Foundation's confidential Awards Committee, acting as an independent body, but on this occasion our Journal's publishers, Elsevier Sequoia SA, learning of the multiplicity of awards and further complexity of authorship, generously subsidized the Prizes so that a respectable amount went to each of the 9 Authors involved.

\section{Additional Themes Initiated}

8) Human-caused Soil-ecological Changes and Their Effect on The Biosphere:- While this vast project is far beyond the capability of our modest little Foundation to do much about, we, with a leading associate in Russia, who pushed the idea, were originators of the Vernadsky International Centre for Biosphere Studies, now established as a unit of the Russian Academy of Sciences and located in Pushchino near Moscow, which, at its initial meeting in June 1991, adopted the project at the urging of the same leader who told us that it was his last ambition to see it in being. As he died soon thereafter, we feel responsible for pushing what is basically his project, and welcome the Foundation's encouragement to do so in memory of the Russians' 'grand old man of soil science', which of course is their traditional subject.

9) Equable Use of The Biosphere's Commons:- These include the world's oceans and atmosphere, and the need to support this theme and also item ' 10 ' is being stressed in Environmental Conservation, especially in this Spring 1992 issue, with the active intention of continuing to encourage them both henceforth.

10) Environmental Impact Assessment Before Financing:- - See item '9' above and note that a representative of the Foundation (who has had many years of banking experience particularly at the international level) will be going to advocate both in every possible way at the UNCED 'Earth Summit' in Rio de Janeiro in June 1992.

11) World Collating Office of Environmental Education:- This has long seemed to us increasingly desirable in view of the vital importance of environmental education, the growth of national and regional bodies (such as NAEE) but continuing inactivity of ISEE, and the need for concerted action globally whenever appropriate. Accordingly an International Workshop on Environmental Education has been arranged by a Brazilian associate to take place in Rio de Janeiro on 4 and 5 June during UNCED — to enable delegates to describe the current state and foreseeable problems of Environmental Education in their respective countries, to adopt a framework of action at the global level, and, if appropriate, to establish an International Council For Environmental Education.

The extent to which the above four additional themes will prove implementable will emerge in due course, a current thought regarding the fourth being that a small office in the International Academy of The Environment might be most appropriate.

NichOLAS PoLuNIN, President \& Editor
Foundation for Environmental Conservation
7 Chemin Taverney (7th \& 8th Floors)
1218 Grand-Saconnex
Geneva, Switzerland.

Nicholas Polunin, President \& Editor 7 Chemin Taverney (7th \& 8th Floors) Geneva, Switzerland.

\title{
Environmental Help for Management
}

A new information service, aimed at helping those with new-found environmental responsibilities in their jobs, is being launched by the British Conservation Foundation. The service is a part of the Environmental Managers' Group, which is intended to help the many people who find that their job-specifications now cover environmental issues for which they may have little or no training. Thus it is clear from the enquiries we receive, that there are many companies which are taking the call to become more environmentally-aware and responsible entirely seriously, but the number which can afford a fulltime, environmentally trained manager can only involve a small proportion.

The launch of the Foundation's Environment Managers' Group coincides with the findings of a survey carried out by the British Institute of Management (BIM), which found that $66 \%$ of respondents to their 'Managing the Environment' questionnaire felt that they or their colleagues would benefit from access to information and training materials that had been prepared and produced specifically for environmental managers.

In addition to general information, the Environmental Managers' Group will also offer members free legal advice provided by two firms of lawyers. The Foundation has run a free 'Environment and the Law' service to the general public, backed by the celebrated firm of Lee \& Pembertons, for over a year. Now it is extending the service by also involving Baker \& McKenzie, one of the world's largest law-firms, to add international advice and perspectives. Fifty-two per cent of the BIM respondents said that their greatest need was for general information on current environmental laws or proposals.

The Conservation Foundation hopes that members will provide much of the expertise which will make practicable an exchange of experience of environmental problems and remedies through fact-sheets and workshops. Backing the initiative is the Conservation Foundation's Founding Director, David Bellamy, who commented:

'Although environmental groups ... are doing vital work, it will be up to industry to solve many of the world's problems. Everywhere I go I meet people who have heard the message, but need help to put their concern into actions. I would like to think that, through the Group, every company listed in Yellow Pages can have their questions answered'.

For further information please contact: David Shreeve, Conservation Foundation, Tel. (071) 8238842.

DAVID SHREEVE, Director The Conservation Foundation

1 Kensington Gore

London SW7 2AR

England, UK. 